\title{
PEMBELAJARAN MENGONVERSI TEKS NEGOSIASI SISWA KELAS X SMA NEGERI 1 SERIRIT DENGAN PENERAPAN METODE BERMAIN PERAN
}

\author{
Made Sri Ardeni , I Nengah Suandi , I Dewa Gede Budi Utama \\ Jurusan Pendidikan Bahasa dan Sastra Indonesia \\ Universitas Pendidikan Ganesha \\ Singaraja, Indonesia
}

email: madesriardeni@gmail.com,nengah_suandi@yahoo.co.id, idgbudiutama@gmail.com

\begin{abstract}
ABSTRAK
Penelitian ini bertujuan untuk mengkaji pembelajaran mengonversi teks negosiasi siswa kelas X SMA Negeri 1 Seririt dengan penerapan metode bermain peran yang meliputi aspek perencanaan, pelaksanaan, evaluasi, dan kendala-kendala yang dihadapi oleh guru bahasa Indonesia di SMA Negeri 1 Seririt. Rancangan penelitian ini adalah deskriptif-kualitatif. Subjek penelitian ini adalah guru bahasa Indonesia di kelas X SMA Negeri 1 Seririt. Objek penelitian ini adalah perencanaan, pelaksanaan, evaluasi, dan kendala-kendala penerapan metode bermain peran dalam pembelajaran mengonversi teks negosiasi. Data yang diperoleh dikumpulkan dengan beberapa metode yakni (1) metode observasi untuk mengamati proses pembelajaran berdasarkan rencana pelaksanaan pembelajaran yang dibuat oleh guru. (2) Metode dokumentasi untuk mengumpulkan data berkaitan dengan keterampilan siswa memerankan teks negosiasi berdasarkan metode bermain peran. (3) metode wawancara untuk mengetahui kendala-kendala yang dihadapi guru saat proses pembelajaran di kelas. Berdasarkan analisis data, diperoleh perencanaan pembelajaran yang dibuat oleh guru sudah sesuai dengan Permendikbud Tahun 2016, hanya saja pada bagian pendekatan pembelajaran, tujuan pembelajaran, dan rencana kegiatan pembelajaran perlu dilengkapi agar mendapatkan RPP yang sempurna. Pelaksanaan pembelajaran menggunakan pendekatan saintifik, kesesuaian pendekatan saintifik terlihat ketika guru sudah mampu merumuskan pertanyaan berdasarkan fasilitas yang sudah disediakan oleh guru yaitu memberikan peluang siswa menonton video negosiasi. Evaluasi sudah sesuai dengan penilaian keterampilan siswa menunjukan total nilai 3.047 dengan rata-rata 87 (kategori baik), 2.927 siswa pemperoleh kategori cukup serta 2.536 siswa pemperoleh kategori cukup. Terdapat dua kendala dalam proses pembelajaran mengonversi teks negosiasi siswa kelas X SMA Negeri 1 Seririt yaitu : (1) cakupan materi yang luas, (2) alokasi waktu kurang.
\end{abstract}

Kata Kunci: pembelajaran, teks negosiasi, bermain peran

\section{ABSTRACT}

This study aims to examine the learning of converting the text of the negotiation of class $X$ students of SMA Negeri 1 Seririt with the application of role playing methods which include aspects of planning, implementation, evaluation, and constraints faced by Indonesian teachers in SMA Negeri 1 Seririt. The design of this research is descriptive-qualitative. The subject of this research is Indonesian teacher in grade X SMA Negeri 1 Seririt. The object of this research is the planning, implementation, evaluation, and constraints of application of role playing method in learning convert negotiation text. The data obtained were collected by several methods, namely (1) observation method to observe the learning process based on the learning implementation plan made by the teacher. (2) Documentation method for collecting data relating to the students' skills plays the text of negotiation based on the role play method. (3) interview method to know the constraints faced by teacher during classroom learning process. Based on the data analysis, the learning plan obtained by the teacher is in accordance with Permendikbud Year 2016, only in the learning approach, the 
learning objectives, and the learning activity plan needs to be completed in order to get the perfect RPP. Implementation of learning using scientific approach, the appropriateness of scientific approach seen when the teacher was able to formulate questions based on facilities that have been provided by the teacher is to provide students the opportunity to watch the video negotiations. The evaluation was in accordance with the student skill assessment showing the total score of 3,047 with an average of 87 (good category), 2,927 students earned enough category and 2,536 students earned enough category. There are two obstacles in the learning process to convert the text of the negotiation of class $X$ students of SMA Negeri 1 Seririt namely: (1) wide material coverage, (2) less time allocation

Keywords: learning, negotiating text, role play

\section{PENDAHULUAN}

Dalam kurikulum 2013, perencanaan pembelajaran diwujudkan dengan menyusun rancangan pelaksanaan pembelajaran (RPP). RPP merupakan rancangan pembelajaran yang dikembangkan secara rinci mengacu pada silabus, buku teks pelajaran, dan buku panduan guru. Pembelajaran memfokuskan pada terbentuknya kompetensi dan karakter siswa secara terintegrasi, utuh, menyeluruh, serta siswa didorong untuk memiliki kesadaran yang tinggi dalam dirinya.

Penelitian ini mengacu pada KD mengonversi teks negosiasi ke dalam bentuk lain sesuai dengan struktur dan kaidah kebahasaan baik secara lisan maupun tertullis. Permasalahan KD tersebut melihat beberapa siswa kurang antusias mengikuti proses pembelajaran karena situasi belajar yang membosankan. Menghadirkan suasana belajar yang menyenangkan. Oleh karena itu, siswa memerlukan metode pembelajaran yang berbasis permainan salah satunya adalah metode bermain peran.

Menurut Sudjana, (2005: 134) metode pembelajaran bermain peran adalah berakting sesuai dengan peran yang telah ditentukan terlebih dahulu untuk tujuan-tujuan tertentu. Selain itu penerapan metode bermain peran yang digunakan dalam pembelajaran bahasa Indonesia mempunyai manfaat penting bagi kehidupan sosial siswa. Menurut Roestiyah (2012:90), bahwa dengan metode bermain peran siswa dapat menghayati peranan apa yang dimainkan mampu menempatkan diri dalam situasi orang lain yang dikehendaki guru. Dengan menghayati peran yang dimainkan dan menempatkan diri dalam situasi orang lain, siswa mengembangkan rasa toleransi terhadap orang lain. Hal ini penting untuk membangun komunikasi atau interaksi sosial yang baik dalam kehidupan bermasyarakat. Interaksi dilakukan di mana saja, bisa di dalam ruangan ataupun di luar ruangan. Interaksi di pasar idenentik dengan tawar menawar, memilih pasar sebagai acuan karena pasar memiliki potensi besar adanya interaksi. Pada umumnya metode bermain peran diterapkan pada pembelajaran menulis drama. Akan tetapi, metode bermain peran dapat digunakan dalam teks negosiasi.

Teks negosiasi adalah suatu teks yang memuat tentang bentuk interaksi sosial yang berfungsi untuk mencapai kesepakatan di antara pihak-pihak yang mempunyai kepentingan yang berbeda Kemendikbud (2013:134). Dalam negosiasi, pihak-pihak tersebut berusaha menyelesaikan perbedaan itu dengan berdialog. Negosiasi dilakukan karena pihak-pihak yang berkepentingan perlu membuat kesepakatan mengenai persoalan yang menuntut penyelesaian bersama. Teks negosiasi memiliki struktur secara garis besar itu hanya pembuka, isi dan penutup. Sedangkan struktur Teks negosiasi secara terperinci dan lebih detailnya mulai dari penjual - pembeli beserta strukturnya yaitu orientasi, permintaan, pemenuhan, penawaran, persetujuan, pembelian, penutup dan karyawan dengan pengusaha beserta strukturnya yaitu orientasi, pengajuan, penawaran, persetujuan, dan penutup.

Menurut Nahari Sabalala (2014:4), negosiasi adalah bentuk interaksi sosial yang berfungsi untuk mencapai kesepakatan diantara pihak-pihak yang 
mempunyai kepentingan yang berbeda. Dalam negosiasi, pihak-pihak tersebut berusaha menyelesaikan perbedaan itu dengan berdialog.

Jlka teks negosiasi dihubungkan dengan kegiatan yang aktif-kreatif artinya tidak hanya paham tetapi dapat mengaplikasikan ke dalam sebuah karya yang memiliki nilai guna, terlebih di dalam mengonversi sebuah teks. Dalam penelitian ini penulis bermaksud untuk mengetahui kemampuan siswa dalam mengonversi teks negosiasi ke dalam bentuk lisan serta teks itu diperankan sesuai kreasi siswa itu sendiri. Berdasarkan pada pemahaman bahwa belajar adalah sebuah perilaku sosial. Strategi ini mendorong siswa untuk berpikir, berbicara, dan kemudian menuliskan suatu topik tertentu. Strategi ini digunakan untuk mengembangkan tulisan dengan lancar dan melatih bahasa.

Saat mengonversi teks negosiasi ke dalam bentuk lisan dikembangkan nilai kreatif peserta didik, mandiri, dan tanggung jawab. Dalam penulisan teks berkembang nilai karakter kreatif karena peserta didik harus mampu merangkum teks negosiasi tersebut kedalam bentuk lisan yang jauh lebih pendek dan padat tanpa menghilangkan makna dari isi teks negosiasi yang ada. Letak kaitan mengonversi teks negosiasi ke dalam bentuk lisan dengan pendidikan karakter adalah dengan peserta didik mampu membuat teks negosiasi kemudian mengubahnya menjadi bentuk lisan dan mengaitkannya pada kehidupan sehari hari. Jadi peserta didik dalam berpendapat, dalam mengungkapkan gagasan atau pemikiran dan mengembangkan kreativitasnya tidak menyinggung orang lain, bertanggung jawab, dan santun.

$$
\text { Kelebihan-kelebihan penerapan }
$$

metode bermain peran, yaitu: (1) membandingkan dan mengkontraskan posisi-posisi yang diambil dalam pokok permasalahan, (2) menerapkan pengetahuan pada pemecahan masalah, (3) menjadikan problem yang abstrak menjadi konkret, (4) melibatkan peserta didik dalam pembelajaran yang langsung, (5) mendorong peserta didik memanipulasi pengetahuan dalam cara yang dinamik, dan
(6) mengembangkan pemahaman yang empatik (Trianto, 2007:100). Adapula keunggulan metode bermain peran, yaitu: (1) peran yag ditampilkan menarik akan mendapat respons dari peerta didik lainya, (2) teknik ini dapat digunakan dalam kelompok besar maupun kecil, (3) membantu peserta didik memahami pengalaman orang lain yang melakukan peran, (4) membantu peserta didik memahami situasi serta memikirkan masalah yang terjadi dalam bermain peran, dan (5) membutuhkan rasa kemampuan dan kepercayaan diri peserta didik untuk berperan dalam menghadapi masalah (Sudjana, 2005:136).

Kelebihan-kelebihan metode

bermain peran sangat memengaruhi pembelajaran mengonversi teks negosiasi. Kelebihan tersebut mampu guru terapkan dengan metode bermain peran ke dalam proses pembelajaran. Pentingnya pembelajaran mengonversi teks negosiasi terhadap pembelajaran di kelas, siswa mampu memerankan teks negosiasi dengan baik dan menumbuhkan rasa senang dan antusias belajar.

Berdasarkan pendahuluan di atas penelitian ini dapat diidentifikasi sejumlah permasalahan, yaitu (1) Siswa belum diarahkan oleh guru untuk membuat hubungan antara pengetahuan yang dimilikinya dengan penerapan dalam kehidupan mereka sebagai anggota keluarga dan masyarakat, (2) Guru belum mampu mengembangkan metode-metode pembelajaran yang berorientasi pada peningkatan intensitas keterlibatan siswa secara efektif di dalam proses pembelajaran, dan (3) Metode pembelajaran guru kurang membuat siswa senang dan terkesan monoton.

Tujuan penelitian ini adalah (1) mendeskripsikan perencanaan pembelajaran mengonversi teks negosiasi siswa kelas X SMA Negeri 1 Seririt dengan penerapan metode bermain peran, (2) mendeskripsikan pelaksanaan pembelajaran mengonversi teks negosiasi siswa kelas $X$ SMA Negeri 1 Seririt dengan penerapan metode bermain peran, (3) mendeskripsikan evaluasi pembelajaran emngonversi teks negosiasi siswa kelas $X$ 
SMA Negeri 1 Seririt dengan penerapan metode bermain peran, dan (4) mendeskripsikan kendala-kendala pembelajaran emngonversi teks negosiasi siswa kelas X SMA Negeri 1 Seririt dengan penerapan metode bermain peran.

Penelitian ini dapat memberikan manfaat yang bersifat teoretis dan praktis kepada berbagai pihak. Secara teoretis, hasil penelitian ini diharapkan mampu memberikan sumbangan konseptual yang edukatif pada pendidikan. Sekaligus sumbangan untuk memperluas teori tentang penerapan metode bermain peran dalam pembelajaran mengonversi teks negosiasi. Secara praktis, penelitian ini bermanfaat bagi guru atau pengajar Bahasa dan Sastra Indonesia, termasuk bagi peneliti sendiri sebagai calon guru Bahasa dan Sastra Indonesia, hasil penelitian ini diharapkan dapat memperkaya bahan ajar ataupun memperkaya wawasan pengajar dalam pembelajaran debat. Bagi siswa, penelitian ini dapat menjadi pedoman dalam pembelajaran Bahasa Indonesia, khususnya pembelajaran mrngonverdi teks negosiasi. Bagi sekolah, hasil penelitian ini dapat dijadikan informasi tindak lanjut terhadap metode pembelajaran di kelas agar lebih inovatif dan kreatif, yang dilaksanakan tidak hanya oleh guru bahasa Indonesia tetapi guru mata pelajaran yang lain. Bagi peneliti lain, hasil penelitian ini dapat dimanfaatkan untuk bahan perbandingan atau referensi ketika melakukan penelitian sejenis.

\section{METODE PENELITIAN}

Rancangan penelitian yang digunakan dalam penelitian ini adalah rancangan deskriptif kualitatif. Penelitian ini diharapkan mampu mendeskripsikan pembelajaran mengonversi teks negosiasi siswa kelas $X$ SMA Negeri 1 Seririt dengan penerapan metode bermain peran.

Subjek penelitian ini adalah guru bahasa Indonesia kelas $\mathrm{X}$, yaitu $\mathrm{Ni}$ Putu Suwastining, S.Pd. Penentuan subjek penelitian ini menggunakan random sampling, sedangkan objek penelitian ini ada empat, yaitu perencanaan, pelaksanaan, evaluasi, dan kendala- kendala penerapan metode bermain peran dalam pembelajaran mengonversi teks negosiasi.

Dalam penelitian ini, peneliti menggunakan metode observasi nonpartisipasi, instrumen yang digunakan adalah pedoman observasi. Peneliti juga menggunakan metode wawancara, instrumen yang digunakan adalah pedoman wawancara, dan metode dokumentasi, instrument pedoman dokumentasi.

Selanjutnya, data dalam penelitian ini dianalisis secara deskriptif kualitatif dengan menggunakan prosedur model analisis (Sugiono, 2007:334), terdiri atas reduksi data, identifikasi data, kelarifikasi data, penafsiran data, penyajian, dan penarikan simpulan. Hasil akhir nanti diperoleh informasi mengenai pembelajaran mengonvesi teks negosiasi siswa kelas $X$ SMA Negeri 1 Seririt.

\section{HASIL DAN PEMBAHASAN}

Data mengenai

rencana pelaksanaan pembelajaran guru terkait pembelajaran mengonversi teks negosiasi siswa kelas X SMA Negeri 1 Seririt, peneliti melakukan pencermatan terlebih dahulu terhadap RPP yang dibuat oleh guru mata pelajaran bahasa Indonesia. Komponen RPP yang disusun oleh guru bahasa Indonesia di kelas X SMA Negeri 1 Seririt, meliputi: identitas sekolah, identitas mata pelajaran, kelas/semester, materi pokok, alokasi waktu, kompetensi inti, kompetensi dasar, indikator, tujuan pembelajaran, materi pembelajaran, metode pembelajaran, media pembelajaran, kegiatan pembelajaran, sumber belajar, pedoman penskoran, dan penilaian keterampilan.

Identitas sekolah dalam RPP guru, sudah tercantum identitas sekolah. Identitas sekolah yaitu SMA Negeri 1 Seririt. SMA Negeri 1 Seririt ini adalah sekolah favorit di Buleleng Barat. Alamat SMA Negeri 1 Seririt ini di Jl. Diponegoro No. 100 Seririt, Buleleng. Identitas mata pelajaran dalam RPP yang dibuat guru sudah sesuai dengan pedoman penyusunan RPP. Guru mencantumkan mata pelajaran yang diajarkan kepada siswa. Dalam RPP, guru bahasa Indonesia 
SMA Negeri 1 Seririt sudah dicantumkan Kelas/ Semester. Kelas diisi dengan Kelas $X$ Semester diisi dengan Semester II (genap).

Dalam RPP guru bahasa Indonesia SMA Negeri 1 Seririt sudah dicantumkan materi pokok yang terkait dengan materi teks negosiasi. Materi teks negosiasi meliputi pengertian teks negosiasi, ciri teks negosiasi, struktur teks negosiasi, dan karakteristik teks negosiasi. Dalam RPP guru sudah dicantumkan alokasi waktu yang diisi dangan $4 \times 45$ menit $(2 \times$ pertemuan), setiap satu jam pelajaran guru hanya mendapatkan 45 menit setiap pertemuan jika batasan waktunya satu jam.

$$
\text { Kompetensi inti (KI) yang }
$$

dicantumkan dalam RPP buatan guru sudah sesuai dengan $\mathrm{KI}$ yang tercantum dalam silabus mata pelajaran bahasa Indonesia di kelas $\mathrm{X}$, yaitu terdapat empat kompetensi inti (KI). Kompetensi Inti-1 (KI1) berkaitan dengan sikap diri terhadap Tuhan Yang Maha Esa, yaitu menghayati dan mengamalkan ajaran agama yang dianutnya, Kompetensi Inti-2 (KI- 2) berkaitan dengan karakter diri dan sikap sosial, yaitu menghayati dan mengamalkan perilaku jujur, disiplin, tanggung jawab, peduli,santun responsif, dan proaktif, Kompetensi Inti-3 (KI-3) tentang pengetahuan terhadap materi yang diajarkan, yaitu memahami, menerapkan menganalisis pengetahuan faktual konseptual, prosedual berdasarkan rasa ingin tahunya tentang ilmu pengetahuan, teknologi, seni, budaya dan harmonia, sedangkan Kompetensi Inti-4 (KI-4) tentang penyajian pengetahuan, yaitu mengolah, menalar, dalam ranah konkret dan ranah abstrak terkait dengan pengembangan dari yang diajarkan di sekolah secara mandiri.

$$
\text { Kompetensi dasar (KD) yang }
$$

tercantum dalam RPP sudah sesuai dengan silabus. Pada RPP yang dibuat guru tercantum 2 KD. Masing-masing KD yakni KD 3.10 Mengevaluasi pengajuan penawaran dan pesetujuan dalam teks negosiasi lisan maupun tertulis dan KD 4.10 Menyampaikan pengajuan, penawaran, persetujuan dan penutup dalam teks negosiasi secara lisan maupun tertulis.
Indikator dijabarkan berdasarkan kompetensi dasar (KD) . Kompetensi dasar 3.10 memiliki tiga indikator yaitu (a) menentukan ciri teks negosiasi, (b) menjelaskan cara menyampaikan pengajuan dan penawaran, (c) mengevaluasi pengajuan, penawaran, dan persetujuan dalam teks negosiasi.

Tujuan pembelajaran tidak dicantumkan di dalam RPP, tetapi disampaikan dalam pelaksanaan pembelajaran oleh guru. Hal ini dikarenakan dalam pembuatan (RPP) guru kekurangan waktu untuk mengisi tujuan pembelajaran melihat banyaknya aktivitas yang guru lakukan di sekolah selain mengajar adalah pengisian administrasi guru ada yang berupa proker (program tahunan) ada pula yang berupa program semester.

Materi pembelajaran yang dicantumkan dalam RPP memuat: fakta, konsep, dan proses yang relevan dengan teks negosiasi. Penggunaan metode pembelajaran sudah sesuai dengan kurikulum 2013. Terdapat beberapa metode yang digunakan dalam pembelajaran yaitu, discovery learning, project based learning, dan problem based learning. Rencana Palaksanaan Pembelajaran yang dibuat guru sudah menggunakan metode discovery learning. Ditunjukkan dengan adanya tahapan-tahapan yang terdapat dalam kegiatan inti pembelajaran dimulai dari stimulus, problem statemet, data collection, data processing, dan generalization.

Dalam RPP guru sudah dicantumkan media pembelajaran berupa power point yang memuat ringkasan materi serta terdapat tayangan video mengenai negosiasi. Adapun teks negosiasi yang terdapat di buku panduan guru dan siswa berupa teks yang memiliki topik yang berbeda-beda dari masing-masing teks yang disediakan. Adanya petunjuk-petunjuk berupa penjelasan terkait teks negosiasi. Buku panduan yang guru gunakan adalah buku panduan bahasa Indonesia Edisi Revisi 2017.

Dalam kegiatan pembelajaran pada bagian pendahuluan guru menyampaikan apersepsi. Pentingnya apersepsi 
disampaikan lebih awal sebelum meranjak ke pembelajaran agar dapat memberikan gambaran kepada siswa terkait pembelajaran yang akan diberikan. Menyampaikan tujuan pembelajaran juga sangat penting agar siswa dapat mengerti pentingnya materi yang disampaikan. Kemudian, kompetensi dasar (KD) akan disampaikan pada proses pembelajaran berlangsung. Bagian inti pembelajaran pada KD 4.10 langkah-langkah tersebut meliputi kegiatan stimulus, problem statement, data collection, data processing, generalization. Kegiatan penutup sudah tercantum kegiatan menyimpulkan materi pembelajaran dan melakukan refleksi terhadap pembelajaran yang telah dilaksanakan.

Sumber belajar yang guru menggunakan" Kementerian Pendidikan dan Kebudayaan Indonesia 2015. Bahasa Indonesia Kelas X. Jakarta: Kementerian Pendidikan dan Kebudayaan Indonesia". Penilaian penskoran yang dibuat guru untuk menilai hasil kerja siswa berupa tes tulis untuk menguji pemahaman siswa dan unjuk kerja untuk penilaian keterampilan memerankan teks negosiasi.

Berdasarkan hasil pencermatan dokumen RPP, dapat disimpulkan bahwa secara keseluruhan RPP yang dibuat oleh guru bahasa Indonesia yang mengajar di kelas X SMA Negeri 1 Seririt sudah sesuai dengan pedoman kompetensi RPP dalam Permendikbud Nomor 22 Tahun 2016 tentang Standar Proses Pendidikan Dasar dan Menengah. Akan tetapi, secara lebih mengkhusus, RPP yang dibuat guru masih terdapat kelemahan yaitu tujuan pembelajaran yang belum dicantumkan di RPP, materi pelajaran dicantumkan subsub materi yang berkaitan dengan materi pokok, pendekatan pembelajaran tidak mencantumkan dalam RPP. Kemudian, kegiatan pembelajaran pada bagian pendahuluan guru tidak merumuskan rencana kegiatan yang dilakukan oleh peserta didik.

Selain perencanaan yang baik pengalaman juga menjamin kompetensi pembelajaran yang baik pula. Guru yang mengajar di kelas X SMA Negeri 1 Seririt sudah menjadi salah satu guru senior sehingga memiliki banyak pengalaman. Pengalaman mengajar lebih dari 20 tahun memberikan banyak ilmu yang didapat diantaranya mampu mengatasi situasi kelas, memiliki banyak strategi pembelajaran agar proses pembelajaran berjalan dengan baik serta diimbangi dengan guru mengikuti pelatihan penyususnan RPP agar mampu meningkat mutu pengajaran guru itu sendiri.

Meskipun telah melakukan banyak pengalaman tetapi, peneliti menemukan tiga kelemahan yang terdapat dalam RPP guru. Kelemahan pertama yakni, tidak dicantumkannya pendekatan pembelajaran. Pendekatan pembelajaran yang digunakan guru saat proses belajar mengajar adalah pendekatan saintifik. Pendekatan saintifik diterapkan dalam pelaksanaan pembelajaran tidak dicantumkan secara jelas di RPP. Pendekatan saintifik yang digunakan guru harus relevan dengan materi pembelajaran agar tercapainya tujuan pembelajaran.

Kelemahan kedua guru tidak mencantumkan tujuan pembelajaran dalam RPP. Namun, guru penyampaikan tujuan pembelajaran di kelas. Dalam hal ini siswa diharapkan mampu memahami apa yang akan siswa capai dalam kegiatan pembelajaran. Ketika tujuan pembelajaran dicantumkan dalam RPP secara jelas, guru akan lebih mudah menyampaikan tujuan pembelajaran dengan baik di dalam kelas. Secara bertahap tujuan pembelajaran itu disampaikan jika tidak ada patokan penulisan dalam RPP yang dibuat guru maka bisa saja guru menyampaikan tujuan pembelajaran tidak secara sistematis, ketidak sistematisan penyampaian maka peserta didik akan bingung memahami apa yang disampaikan guru.

Kelemahan terakhir guru tidak mencantumkan rencana kegiatan. Guru perlu merumuskan kegiatan-kegiatan yang dilakukan oleh peserta didik. Dalam Permendikbud Nomor 81A Tahun 2013 menyatakan bahwa kegiatan pendahuluan, guru perlu menyiapkan peserta didik secara psikis dan fisik untuk mengikuti proses pembelajaran, mengajukan pertanyaan tentang materi yang sudah dipelajari dan materi yang akan dipelajari. Rencana 
kegiatan pembelajaran yang dilakukan oleh peserta didik tidak dicantumkan dalam RPP. Penyusunan RPP dibuat menyesuaikan dengan pedoman serta banyak variasi dalam pedoman penyusunan RPP dengan waktu yang terbatas bisa mengakibatkan banyaknya kelemahan yang ditemukan.

Data mengenai pelaksanaan pembelajaran diperoleh berdasarkan hasil observasi. Hasil observasi yang telah dilakukan menunjukkan bahwa pelaksanaan pembelajaran meliputi tiga tahap, yaitu (1) kegiatan pendahuluan, (2) kegiatan inti, dan (3) kegiatan penutup.

Pada kegiatan pendahuluan pertama-tama guru dan peserta didik mengucapkan salam pembuka "Om Swastyastu". Selanjutnya, guru melaksanakan administrasi kelas, seperti mengabsen peserta didik, dan mengisi jurnal kelas. Di samping melaksanakan administrasi, guru juga melihat kesiapan peserta didik untuk mengikuti pelajaran dengan memerhatikan buku yang sudah dipersiapkan oleh peserta didik. Setelah itu, guru melakukan kegiatan apersepsi dengan cara mengajukan pertanyaan-pertanyaan yang berkaitan dengan materi pembelajaran yang akan dipelajari dengan pengalaman peserta didik atau pembelajaran sebelumnya. kegiatan memotivasi siswa dengan cara meminta siswa untuk menepuk tangan sebanyak mungkin sampai siswa merasa senang dan ceria kemudian guru menunjuk siswa dengan menyiapkan sebuah pertanyaan mengenai negosiasi. Pertanyaan guru kepada salah satu siswa di kelas yakni "Apa yang kamu ketahui tentang negosiasi?". Pada kegiatan inti, guru membimbing peserta didik untuk memahami materi dengan lima tahapan, yaitu stimulus, problem statement, data collection, data processing, dan generazation.

Dalam kegiatan stimulus, peserta didik diarahkan untuk dapat mengetahui teknik menulis teks negossiasi dengan membaca materi tentang teks negosiasi yang berkaitan dengan pengertian teks negosiasi, struktur teks negosiasi, dan karakteristik teks negosiasi. Setelah itu, peserta didik dituntun untuk dapat mengamati beberapa hal penting bagaimana cara memerankan teks negosiasi, utamanya yang berkaitan dengan struktur teks negosiasi yang bersifat informal atau formal. Kemudian guru meminta siswa memperhatikan sebuah video dalam tanyangan power point dan siswa diminta menemukan apa saja yang terdapat dalam video tersebut mengenai teks negosiasi.

Dalam kegiatan problem statement, peserta didik diajurkan untuk dapat mengajukan pertanyaan-pertanyaan yang berkaitan dengan teks negsosiasi, baik itu mengenai teknik penulisan informal dan formal, maupun struktur dan karakteristi teks negosiasi. Ketika kegiatan tanya-jawab ini berlangsung tidak semua peserta didik terlibat bertanya. Hanya beberapa peserta didik yang mengajukan pertanyaan kepada guru. Salah satu pertanyaan siswa "Adakah ketentuan yang harus ada dalam bernegosiasi?". Guru langsung memberikan jawaban serta penguatan terhadap partisipasi peserta didik dan guru juga sudah menunjukkan sikap terbuka terhadap respon peserta didik. adapun jawaban yang guru sampaikan kepada salah satu siswa di kelas "Dalam bernegosiasi adanya beberapa syarat untuk memenuhi tercapainya negosiasi yang baik yaitu: (1) dilakukan dengan santun, (2) tidak ada tekanan atau paksaan, dan (3) saling menguntungkan".

Dalam kegiatan data collection, peserta didik diminta untuk mengumpulkan data atau informasi mengenai teknik penulisan teks negosiasi. Adapun tujuan mengumpukan data ini, yaitu agar peserta didik dapat menyusun teks negosiasi dengan baik. Selain itu, cara yang lain untuk dapat mengumpulkan data atau informasi mengenai penulisan teks negosiasi, bisa didapat dari buku paket siswa, dan internet. Setelah itu, peserta didik diarahkan untuk mencermati contoh teks negosiasi bersifat informal dan formal yang sudah ditampilkan oleh guru berupa video. Setelah data collention dilakukan peserta didik diarahkan untuk menentukan topik untuk memproduksi teks negosiasi. Sebelum kegiatan menyusun teks negosiasi 
berlangsung, guru menyampaikan beberapa topik yaitu: (1) pasar, (2) tempat makan, (3) liburan, (4) menjaga rumah, dan (5) sekolah. Beberapa topik yang guru sampaikan meliputi kegiatan sehari-hari peserta didik, agar siswa mampu memahami dengan baik topik yang disampaikan.

Dalam data processing, peserta didik berdiskusi terkait penulisan teks negosiasi yang akan diproduksi. Selanjutnya, peserta didik mulai menulis teks negosiasi yang bersifat informal dan formal berdasarkan kerangka yang telah dibuat serta tidak lupa peserta didik harus memperhatikan struktur teks negosiasi. Kemudian, peserta didik menyimpulkan cara memperoduksi teks negosiasi yang bersifat informal dan formal dengan memperhatikan struktur, kaidah, dan karakteristik teks negosiasi.

Pada kegiatan generazation, peserta didik berdiskusi terkait hasil tulisan yang telah dibuat, dengan cara menilai hasil pekerjaan temannya. Kemudian, dilanjutkan dengan melaporkan hasil diskusi di depan kelas. Dalam pelaksanaan pembelajaran peserta didik sudah mampu merumuskan pertanyaan berdasarkan fasilitas yang sudah disediakan oleh guru yaitu memberikan peluang siswa menonton video, negosiasi serta contoh teks negosiasi pada buku paket siswa. Dalam pelaksanaan guru sudah memfasilitasi peserta didik untuk mengolah/menganalisis informasi sehingga peserta didik mampu membuat simpulan dari materi yang telah diajarkan.

Pada kegiatan penutup, guru dan peserta didik bersama-sama melakukan refleksi dan membuat rangkuman materi yang telah diajarkan. Melakukan refleksi dan membuat rangkuman dengan melibatkan peserta didik (Widyastanto, 2004:206). Guru sudah mengumpulkan hasil kerja siswa sebagai bahan portofolio. Ketika proses belajar mengajar berakhir guru meminta siswa merangkum materi yang telah dipelajari ketika pembelajaran berlangsung. Kegiatan tersebuat dimulai dari awal pelajaran sampai akhir pelajaran. Hal ini menguji apakah siswa sudah memahami apa yang dipelajarinya. Setelah menyimpulkan materi pembelajaran, guru memberikan peluang siswa untuk bertanya terkait materi yang diajarkan atau materi yang akan diajarkan pada pertemuan selanjutnya. Kemudian, guru merencanakan tindak lanjut pembelajaran untuk pertemuan selanjutnya.

Strategi pelaksanaan kegiatan belajar siswa SMA/SMK yang dikehendaki sesuai kurikulum 2013 adalah dengan menerapkan pendekatan saintifik (scientific approach) yang digunakan guru saat proses pembelajaran. Dilihat dari segi pelaksanaan pembelajaran, secara umum guru sudah melaksanakan pembelajaran sesuai dengan Permendikbud Nomor 22 tahun 2016. Namun, masih terdapat beberapa ketidaksesuaian antara RPP dengan pelaksanaan pembelajaran di dalam kelas. Ketidaksesuaian tersebut salah satunya adalah rencana kegiatan pembelajaran dan tujuan pembelajaran yang disampaikan oleh guru saat pelaksanaan pembelajaran tidak dicantumkan dalam RPP. Menurut Kunandar (2007:263) menyatakan bahwa fungsi RPP adalah sebagai acuan guru untuk melaksanakan kegiatan pembelajaran agar pembelajaran berlangsung secara lebih terarah dan berjalan efektif serta efisien.

Dalam RPP buatan guru, khususnya pada bagian pendahuluan guru tidak mencantumkan kegiatan menyampaikan rencana kegiatan pembelajaran dan tujuan pembelajaran kepada siswa, padahal dalam Permendikbud Nomor 22 Tahun 2016 disebutkan bahwa salah satu kegiatan yang harus dilakukan oleh guru pada bagian pendahuluan, yaitu menyampaikan garis besar cakupan materi dan penjelasan tentang kegiatan yang dilakukan peserta didik. Pentingnya tujuan pembelajaran disampaikan kepada siswa. Sementara, menurut Arikunto (2005:4) menyatakan pencapaian tujuan pembelajaran yang berupa prestasi belajar, merupakan hasil dari kegiatan belajar-mengajar semata. Berdasarkan hal tersebut, rencana kegiatan pembelajaran dan tujuan pembelajaran yang disampaikan guru ketika kegiatan belajar mengajar berlangsung penting untuk diterapkan dalam RPP, agar proses 
pembelajaran di dalam kelas dapat berlangsung secara lebih terarah, serta dapat berjalan dengan efektif dan efisien.

Ketidaksesuaian antara RPP dan pelaksanaan pembelajaran juga tampak pada pendekatan pembelajaran. RPP yang dibuat guru tidak mencantumkan pendekatan pembelajaran. Tetapi, di dalam pelaksanaan pembelajaran guru menerapkan pendekatan pembelajaran Dilihat dari tahapan-tahapan kegiatan dapat diketahui pendekatan saintifik dilihat dari tahapan (1) mengamati, menanya, mengumpulkan informasi, mengolah informasi, dan mengkomunikasikan. Jadi, perlu adanya kesesuaian antara RPP yang telah dirancang dengan pelaksanaan pembelajaran. Penyususnan RPP yang belum sempurna mengakibatkan proses pembelajaran menjadi tidak efektif harus ada pedoman dalam setiap proses pembelajaran maupun penilaian.

Evaluasi merupakan kegiatan yang terencana untuk mengetahui keadaan suatu objek dengan menggunakan instrument dan membandingkan hasil dengan tolok ukur untuk memperoleh kesimpulan (Sutikno, 2007:73). Evaluasi dapat diperoleh informasi yang akurat tentang penyelenggaraan pembelajaran dan keberhasilan belajar siswa (Hamalik,2005:29). Ralph Tyler (dalam Arikunto, 2012:3), mengemukakan bahwa evaluasi merupakan sebuah proses pengumpulan data untuk menentukan sejauh mana, dalam hal apa, dan bagaimana tujuan pendidikan sudah tercapai.

Data mengenai evaluasi diperoleh berdasarkan dokumentasi yang dilakukan peneliti. Evaluasi yang dilakukan oleh guru, yaitu (1) penilaian kompetensi sikap yang berupa observasi sikap peserta didik dan penilaian jurnal; (2) penilaian kompetensi pengetahuan yang berupa tes tulis atau penugasan; dan (3) penilaian kompetensi keterampilan yang berupa tes unjuk kerja/praktek, projek, dan portofolio.

Guru melakukan penilaian kompetensi sikap melalui observasi, penilaian diri, penilaian antarteman, dan jurnal. Instrument yang digunakan untuk observasi, penilaian diri, dan penilaian antarteman adalah daftar cek. Ketika komponen yang diharapakan menunjukan sesuai siswa akan menandainya berupa cek dan jurnal berupa catatan pendidikan. Pada saat itu, guru melakukan observasi terhadap sikap peserta didik, observasi yang dilakukan merupakan teknik penilaian yang dilakukan secara berkesinambungan dengan menggunakan indera, baik secara langsung maupun tidak langsung serta menggunakan pedoman observasi yang berisi sejumlah indikator perilaku yang diamati (disesuaiakan dengan permintaan KD-2).

ini dilakukan untuk mengetahui perkembangan peserta didik dalam memahami teknik penulisan teks negosiasi dan kemampuan peserta didik. Kegiatan penilaian ini meliputi: tes tulis atau penugasan. Tes tulis yang diberikan kepada peserta didik belum disediakan rubrik penilaiannya. Dalam penilaian tes tulis siswa diberikan berupa soal esai sejumlah empat soal yang berisikan tentang materi yang disampaikan oleh guru. Hal ini dibuat untuk menguji pemahaman siswa terkait materi teks negosiasi. Selanjutnya, guru memberikan penugasan (tugas) peserta didik untuk menulis teks negosiasi secara berkelompok sesuai topik yang ditentukan. Kemudian, guru menilai hasil tugas siswa berupa aspek yang ditentukan. Ketika isi dan topik tidak sesuai dalam teks yang dibuat, maka nilai yang diperoleh oleh siswa sangat rendah dan tidak sesuai KKM yaitu 72 .

Setelah penilaian pengetahuan dilakukan, guru melakukan penilaian terhadap keterampilan peserta didik yang meliputi: peniaian keterampilan dengan unjuk kerja/praktik, projek, dan portofolio. Ketiga penilaian keterampilan tersebut dalam kenyataanya sudah diintergrasikan, pertama-tama peserta didik melakukan perancangan dengan menentukan topik. Topik yang sudah ditentukan sebelumnya oleh guru yakni: (1) pasar, (2) tempat makan, (3) liburan, (4) menjaga rumah, dan (5) sekolah. Tahap berikutnya adalah mendiskusikan dan menukarkan pekerjaan yang dibuat dengan teman sebangku, setelah itu peserta didik melaporkan hasil 
diskusi oleh peserta didik sebagai bahan portofolio.

Selain ketiga penilaian di atas peneliti memaparkan hasil nilai siswa terkait penilaian keterampilan memerankan teks negosiasi. Dapat disimpulkan bahwa masing-masing kelas meliputi : kelas X MIA 1, Kelas X BABUD 2, dan kelas X IIS 1 memiliki hasil nilai yang berbeda-beda. Dilihat dari hasil rata-rata masing-masing kelas. Apalagi ada dua siswa yang memperolah hasil nilai di bawah KKM. Faktor utamanya adalah kurangnya percaya diri yang dimiliki oleh siswa. Hasil nilai yang bervariasi, serta ketiga tabel di atas memiliki beberapa kategori yang bervariasi pula. Dilihat dari kelas X MIA 1 mendapatkan hasil rata-rata 87,06 dengan kategori baik, kelas $X$ BABUD 2 mendapatkan hasil rata-rata 81,31 dengan kategori cukup, sedangkan kelas X IIS 1 mendapatkan hasil rata-rata 76,84 nilai yang paling rendah dibandingkan kelas $X$ MIA 1 dan kelas $X$ BABUD 2. Kategori kelas X IIS 1 adalah cukup. Dapat di jelaskan bahwa kategori dibagi menjadi 4 yaitu: jumlah nilai 93-100 mendapat kategori sangat baik, jumlah nilai 83-92 mendapat kategori baik, lalu jumlah nilai 7282 mendapat kategori cukup, dan yang terakhir jumlah nilai 62-71 mendapat kategori kurang. Ketiga tabel di atas menunjukan hasil yang cukup baik, siswa memerankan teks negosiasi, meskipun terlihat ada 2 siswa yang mendapatkan kategori kurang di kelas X IIS 1.

Evaluasi merupakan kegiatan yang terencana untuk mengetahui keadaan suatu objek dengan menggunakan instrument dan membandingkan hasil dengan tolak ukur untuk memperoleh kesimpulan (Sugiono, 2007:73).Mengenai evaluasi yang guru lakukan untuk mengetahui perkembangan peserta didik, yaitu penilaian kompetensi sikap, penilaian kompetensi pengetahuan, dan penilaian kompetensi keterampilan. Secara umum, ketiga penilaian tersebut sudah dilaksanakan oleh guru dan sudah sesuai dengan Permendikbud Nomor 81A Tahun 2013. Secara lebih mengkhusus, evaluasi yang dilakukan oleh guru memiliki beberapa kelemahan, salah satunya adalah tidak disediakannya rubrik penilaian tes tulis atau penugasan. Rubrik penilaian tes tulis atau penugasan juga tidak dibuat guru karena guru memberikan penilaian secara langsung kepada peserta didik ketika siswa menjawab soal yang diberikan. Rubrik penilaian sikap pun guru belum membuatnya, kelemanan semacam ini membuat tidak objektifnya penilaian yang guru berikan ke peserta didik. Untuk dapat mengevaluasi hasil belajar peserta didik, guru seharusnya berpedoman pada rubrik penilaian agar evaluasi bisa lebih terarah. Apabila rubrik tidak ada, maka guru akan kesulitam untuk mengetahui hasil belajar peserta didik.

Evaluasi pembelajaran terkait hasil persentase mendapat hasil yang menyatakan "ada" dan "sesuai" adalah $100 \%$. Hal ini disebakan karena penilaian sikap, pengetahuan, dan keterampilan sudah memiliki pedoman yang guru gunakan dalam menilai hasil tes (ulangan harian) dan menilai ujuk kerja/praktik. Tidak hanya pada materi teks negosiasi tetapi semua materi pelajaran pun guru menggunakan pendoman yang sama namun, menyesuaikan juga dengan permintaan kompetensi dasar dan indikator dari masing-masing materi pelajaran. Dari hasil nilai keterampilan siswa total nilai yang paling tinggi adalah Kelas $X$ Mia1 yang siswanya berjumlah 35 orang dengan total nilai 3.047 dan mendapatkan rata-rata 87.06. Melihat status kelas $X$ Mia 1 ini adalah kelas unggulan siswa di sana memiliki pemahaman di atas rata-rata karena melihat nilai masing-masing siswa tidak ada yang dibawah KKM serta nilai 72 hanya 2 orang dari 35 siswa daam satu kelas. Berbeda halnya dengan kelas $X$ Babud 2 jumlah siswa dalam satu kelas adalah 36 orang dan memiliki total nilai 2.927 dengan rata-rata 81.31 meskipun kelas X Babud 2 adalah siswa bahasa tidak menutup kemungkinan siswa bahasa akan lebih unggul dalam bidang bahasa. Keadaan siswa dalam satu kelas akan memiliki karakter yang berbeda dan pemahaman yang berbeda pula.

Kemudian berbeda pula dengan kelas $X$ lis 1 yang nilainya rendah dengan kelas unggulan. Kelas $X$ lis 1 yang jumlah siswa dalam satu kelas adalah 33 orang 
dengan jumlah nilai 2.536 serta rata-rata yang didapat adalah 76.84. Rata-rata yang hampir dibawah KKM ini membuktikan siswa kelas $X$ lis 1 dalam menampilkan semua teks masih saja ada keragu-raguan yang dimilikinya. Tetapi, pada umumnya semua kelas pasti memiliki kelebihan dan kekurangan. Selain hasil persentase peserta didik juga mendapatkan nilai berupa kategori penilaian yakni: sangat baik, baik, cukup, dan kurang. Ketiga kelas tersebut memiliki banyak variasi kategori, dimulai dengan kategori baik, cukup, dan kurang. Dapat dilihat pada kelas X Mia 1 yang mendapat hasil baik berjumlah 26 siswa dan yang cukup berjumlah 9 siswa. Kategori baik dengan rata-rata 87.06. kemudian kelas $X$ Babud2 yang mendapat kategori baik 19 siswa dan kategori cukup 23 siswa, sedangkan kelas $X$ lis1 mendapatkan 3 kategori yaitu: baik, cukup, dan kurang, dapat dilihat bahwa mendapat kategori baik 4 siswa, kategori cukup 27 siswa, sedangkan kategori kurang 2 siswa. Kedua kelas yang mendapatkan kategori berdasarkan nilai rata-rata yakni kelas $X$ Babud 2 dan lis1 adalah kategori cukup.

Berdasarkan hasil wawancara langsung dengan guru bahasa Indonesia maka ditemukan beberapa kendala dalam pembelajaran mengonversi teks negosiasi dengan penerapan metode bermain peran. Beberapa pertanyaan mengenai kendala guru dilihat dari segi perencanaan, pelaksanaan, dan evaluasi pembelajaran. Dilihat dari segi perencanaan pembelajaran, tidak ada kendala yang begitu berarti. Perencanaan pembelajaran menyangkut silabus dan RPP. Silabus, disusun oleh Kementerian Pendidikan dan Kebudayaan, sedangkan RPP disusun oleh guru sesuai dengan pendoman penyusunan RPP kurikulum 2013. Untuk menyusunan RPP sudah disediakannya panduan dan pedoman kurikulum 2013. Hanya saja hambatan guru menyusun RPP adalah kekurangan waktu dalam membuat RPP karena pembagian mata pelajaran juga diadakan diawal tahun sehinga guru harus membuat semua RPP sebelum melakukan pembelajaran.

Pada tahap pelaksanaan
pembelajaran, guru menemukan beberapa kendala. Kendala utama pada tahap pelaksanaan pembelajaran adalah alokasi waktu, cakupan materi yang sangat luas. Pada tahapan kegiatan inti seperti stimulus, problem statement, data collection, data processing, dan generazation tidak semua tahapan kegiatan itu terlaksana sepenuhnya. Untuk menyiasati hal tersebut, guru meringkas materi yang diajarkan kepada siswa. Selain itu, keterbatasan pengetahuan siswa juga menjadi kendala dalam pelaksanaan pembelajaran bahasa Indonesia materi teks negosiasi. Keterbatasan pengetahuan yang dimaksud adalah hal yang disampaikan dalam buku tidak sesuai dengan lingkungan sekitar siswa.

Kendala yang hanya dirasakan guru di evaluasi yaitu, guru di SMA Negeri 1 Seririt merasa penilaian pada kurikulum 2013 sangat banyak, belum lagi jumlah aspek dari setiap penilaian yang harus dijabarkan. Pertama penilian sikap, hal ini berkaitan dengan aktivitas atau perilaku siswa di kelas. Kedua penilaian pengetahuan hal ini berkaitan dengan sejauh mana siswa dalam menguasai materi yang telah disampaikan. Bentuk tes yang dapat dilakukan adalah tes tertulis dan tes lisan. Ketiga keterampilan dengan contohnya pemberian tugas proyek berupa membuat suatu karya.

Selain itu, kendala yang dihadapi guru adalah kesesuaian antara waktu yang disediakan dengan materi pembelajaran. Pada jenjang SMA, alokasi waktu untuk satu jam pelajaran adalah 45 menit. Pelajaran bahasa Indonesia mendapat alokasi waktu selama $2 \times 45$ menit untuk satu kali pertemuan, sehingga cakupan materi yang terlalu luas dan kurangnya pemahaman siswa memehami materi yang disampaikan guru. Oleh karena itu, guru sebaiknya mencari contoh-contoh lain yang lebih relevan dengan kondisi di sekitar siswa agar siswa lebih mudah dalam memahami materi pelajaran. Keadaan ini sangat sulit untuk terselesaikan tepat waktu

\section{SIMPULAN DAN SARAN}

Berdasarkan masalah yang diajukan, dapat disimpulkan hal-hal sebagai berikut: 
1. Perencanaan pembelajaran mengonversi teks negosiasi dengan penerapanmetode bermain peran memiliki beberapa kelemahan yakni materi pelajaran tidak dicantumkan di dalam RPP. tujuan pembelajaran tidak dicantumkan dalam RPP. tetapi, disampaikan saat proses pembelajaran berlangsung. rencana kegiatan tidak dicantukan pada RPP. padahal rencana kegiatan penting dicantumkan agar guru lebih sistematis saat menyampaikannya. pendekatan pembelajaran tidak dicantumkan tetapi diterapkan langsung dalam proses pembelajaran.

2. Pelaksanaan pembelajaran disesuaikan dengan pendekatan saintifik yang guru terapkan agar kemampuan siswa memahami materi yang disampaikan dapat memberikan hasil yang lebih baik.

3. Evaluasi pembelajaran mengonversi teks dengn penerapan metode bermain peran. dilihat dari penilaian keterampilan siswa mendapatkan kategori baik dengan total nilai 3.047, katagori cukup 2927 dan 2.536 .

4. Kendala yang diperoleh guru yakni a. cakupan materi yang luas membuat guru harus meringkas materi dan meminta siswa membaca materi pada buku panduan, b. alokasi waktu yang kurang membuat guru harus membuat strategi mengajar agar pembelajaran bisa efektif dan efesien.

Berdasarkan hasil penelitian dan simpulan di atas, saran yang dapat disampaikan daam penelitian ini adaah sebagai berikut.

1. Bagi pembaca, hasil penelitian ini diharapkan memberikan wawasan terkait dengan pembelajaran mengonversi teks negosiasi dengan penerapan metode bermain peran.

2. Bagi calon peneliti, penelitian ini dapat dijadikan sebagai salah satu alternatif untuk melakukan penelitian, serta metode bermain peran dapat diteliti dengan metode lain.

\section{DAFTAR PUSTAKA}

Arikunto,Suharsimi.2005. Dasar-Dasar Evaluasi Pendidikan. Jakarta:PT Bumi Aksara.

Hamalik, Oemar. 2009. Proses Belajar Mengajar. Jakarta: Bumi Aksara.

Kemendikbud. 2013. Buku Guru: Bahasa Indonesia Ekspresi Diri dan Akademik untuk Kelas $X$. Jakarta: Kementerian Pendidikan dan Kebudayaan.

Permendikbud.2016. Standar proses dan menengah. Jakarta: Kementerian Pendidikan dan Kebudaya

Roestiyah. 2012. Strategi Belajar Mengajar. Jakarta: Rineka Cipta.

Sudjana, Nano. 2005. Dasar-Dasar Proses Belajar Mengajar. Bandung: Sinar Baru.

Sugiono. 2007. Metode Penelitian Pendidikan:Pendekatan Kuantitatif, Kualitatif Dan R\&D. Bandung: Alfabeta.

Trianto. 2007. Model-Model Pembelajaran Inovatif Berorientasi Konstruktivistik (Konsep, Landasan Teoritis-Praktis Dan Implementasinya). Jakarta: Prestasi Pustaka.

Widyastanto, Harry. 2014. Pengembangan Kurikulum di Era Otonomi Daerah: Dari Kurikulum 2004, 2006, Ke 2013. Jakarta: Bumi Aksara

Sabalala, Nahari. 2014. Artikel :Mengabstrasi Teks Negosiasi. Tersedia: Http://Naharisabalala.Blogspot.Com/ 2014/Mengabstrasi-Teks Negosiasi. Html.Diakses Pada Tanggal 5 Desember 2017.

Sutikno, M. Sobry. 2007. Menggagas Pembelajaran Efektif dan Bermakna. Mataran: NTP Press. 
